\title{
Genetic factors that may affect the risk of developing thrombosis in patients with myeloproliferative disorders
}

\section{Type}

Research paper

\section{Keywords}

polymorphism, thrombosis, genetic factor, myeloproliferative disorders

\begin{abstract}
Introduction

Patients with Philadelphia-negative (Ph-) myeloproliferative neoplasms: primary myelofibrosis, essential thrombocythemia and polycythemia vera; often develop thrombotic events. It was suggested that the genetic variants that are responsible for blood coagulation and elevated homocysteine level play causal role in the occurrence of thrombosis. Our aim was to evaluate the single nucleotide polymorphisms in PROS1, EPCR, PROC, MTHFR, MS genes and their associations with the risk of developing thrombosis as well as clinical characteristics in patients with myeloproliferative disorders.
\end{abstract}

Material and methods

The screening of PROS1 g.66847T>C, EPCR c.4678G >C, EPCR c.6936A>G, PROC c.565C>T, MTHFR c.677C>T, MTHFR c.1298A>C, MS c.2756A>G polymorphisms was performed at Lithuanian University of Health Sciences, Kaunas, Lithuania. The PCR-RFLP method was applied.

Results

After genotyping 88 patients with $\mathrm{Ph}$ - myeloproliferative disorders, the association was found between venous thrombosis and MTHFR c.1298A $>C(p=0.019)$. Regression analysis revealed that carriers of PROS1 66847TC, EPCR 4678GC, 6936AG or GG, PROC 565CT or TT, MTHFR 677CT, MS 2756AG genotypes were associated with a lower risk of developing venous thrombosis. EPCR 6936AG genotype could be considered as a protective factor against arterial thrombosis. Genotypes PROC 565CT and 565TT were associated with a lower risk of decreased levels of MPV, 565TT carriers were less likely to develop arterial or venous thrombosis, compared with those carrying the CC or CT genotype.

Conclusions

It can be concluded that more research into these polymorphisms needs to be performed, since there are many conflicting results published regarding the complexity of the possible interactions between these gene variants and predisposition to thrombotic events. 
Genetic factors that may affect the risk of developing thrombosis in patients with myeloproliferative disorders

Running title: SNPs AFFECTING THROMBOSIS IN PMF, ET, PV 


\section{ABSTRACT}

Introduction: Patients with Philadelphia-negative $(\mathrm{Ph}-)$ myeloproliferative neoplasms: primary myelofibrosis, essential thrombocythemia and polycythemia vera; often develop thrombotic events. It was suggested that the genetic variants that are responsible for blood coagulation and elevated homocysteine level play causal role in the occurrence of thrombosis. Our aim was to evaluate the single nucleotide polymorphisms in PROS1, EPCR, $P R O C, M T H F R, M S$ genes and their associations with the risk of developing thrombosis as well as clinical characteristics in patients with myeloproliferative disorders.

Materials and methods: The screening of $P R O S 1$ g.66847T $>\mathrm{C}, E P C R$ c.4678G $>\mathrm{C}, E P C R$ c. $6936 \mathrm{~A}>\mathrm{G}, P R O C$ c $.565 \mathrm{C}>\mathrm{T}, M T H F R$ c. $677 \mathrm{C}>\mathrm{T}, M T H F R$ c. $1298 \mathrm{~A}>\mathrm{C}, M S$ c. $.2756 \mathrm{~A}>\mathrm{G}$ polymorphisms was performed at Lithuanian University of Health Sciences, Kaunas, Lithuania. The PCR-RFLP method was applied.

Results: After genotyping 88 patients with $\mathrm{Ph}$ - myeloproliferative disorders, the association was found between venous thrombosis and MTHFR c.1298A $>\mathrm{C}(\mathrm{p}=0.019)$. Regression analysis revealed that carriers of PROS1 66847TC, EPCR 4678GC, 6936AG or GG, PROC 565CT or TT, MTHFR 677CT, MS 2756AG genotypes were associated with a lower risk of developing venous thrombosis. EPCR 6936AG genotype could be considered as a protective factor against arterial thrombosis. Genotypes $P R O C$ 565CT and 565TT were associated with a lower risk of decreased levels of MPV, 565TT carriers were less likely to develop arterial or venous thrombosis, compared with those carrying the $\mathrm{CC}$ or $\mathrm{CT}$ genotype.

Conclusions: It can be concluded that more research into these polymorphisms needs to be performed, since there are many conflicting results published regarding the complexity of the possible interactions between these gene variants and predisposition to thrombotic events. 
Keywords: genetic factor; polymorphism; myeloproliferative disorders; thrombosis. 


\section{INTRODUCTION}

Myeloproliferative neoplasms (MPNs), by definition, are clonal hematologic diseases that occur by overproduction of active blood cells [1]. The group of Philadelphia-negative (Ph-, non $B C R-A B L)$ myeloproliferative neoplasms, polycythemia vera (PV), essential thrombocythemia (ET), and primary myelofibrosis (PMF), are known for their different phenotypes but similar complications [2]. Primary myelofibrosis specifically is a clonal stem cell disorder that is characterized by chronic myeloproliferation, megakaryocytic hyperplasia and the presence of the myeloid series immature cells in the circulating blood [3]. PMF is a relatively rare disease and affects approximately 1 in 500.000 people worldwide. Essential thrombocythemia is specifically defined by the thrombocytosis and thrombotic or hemorragic events. This disease can also progress into secondary myelofibrosis and occurs in approximately 2 cases in 100000 per year [4]. Polycythemia vera is characterized by uncontrollable blood cells proliferation and accumulation (white blood cells, red blood cells, platelets) [5]. The incidence of PV is at least 2 per 100000 [6]. Common complications for these diseases are thrombotic events, which can often be the main cause of death $[7,8]$. The incidence of thrombotic complications varies between disease types. They occur in 7.2$15.0 \%$ patients with PMF, in $19.0-32.0 \%$ patients with ET, and in $30.0-41.0 \%$ patients with PV [9-12]. It is known that thrombotic complications may be genetic or acquired. Pathogenesis of thrombosis in MPNs is complex, but not fully understood yet [13]. The protein $\mathrm{C}$ (PROC) anticoagulant pathway plays a key role in controlling thrombosis. PROC is activated on endothelium by the thrombin-thrombomodulin-endothelial protein C receptor (EPCR) complex [14]. In the presence of cofactor protein S (PROS1), activated protein $\mathrm{C}$ proteolytically inactivates coagulation factors VIIIa and $\mathrm{Va}$, thereby inhibiting clot formation. By binding to EPCR and protease-activated receptor-1, PROC also exerts antiinflammatory and cytoprotective effects on a variety of cell types [15]. It is known that 
deficiencies in one of the three natural anticoagulants, antithrombin, protein $\mathrm{C}$ or protein $\mathrm{S}$ are inherited forms of thrombophilia, which have been linked to venous thrombosis (VT). Moreover, mutations and polymorphisms in the PROC and PROS1 genes are associated with thrombotic disease [16-20].

As mentioned, EPCR, a transmembrane protein expressed on the endothelium of large vessels, is involved in the activation of protein $\mathrm{C}$ anticoagulant pathway by binding PROC and enhancing its activation [21]. It increases 5-fold the activation efficiency of PROC leading to markedly elevated anticoagulant activity [22]. Thus, the involvement of EPCR in the anticoagulant pathway of hemostasis suggests a potential role in the pathogenesis of thrombosis [23]. Blocking of EPCR seems to accelerate thrombus development in vivo [24]. Furthermore, polymorphisms in EPCR gene have been studied regarding their involvement in the development of thrombosis [25], but conclusions were questioned [26, 27].

Several key enzymes, including 5,10-methylenetetrahydrofolate reductase (MTHFR), methionine synthase (MS) and methionine synthase reductase (MTRR), are important in homocysteine metabolism and therefore in methylation reactions [28-30]. Disturbed function of the enzymes results in hyperhomocysteinemia and may cause thrombophilia [31]. It has been suggested that MTHFR, MS and MTRR genes are involved in the aetiology of malignancies. The substitutions in MTHFR gene may be associated with myeloproliferative neoplasms risk and disease progression. MTHFR has been described as one of the candidate genetic risk factors for thrombosis. MTHFR association with thrombotic events has been extensively studied over the past decade, however, the results were inconclusive [31-35]. Moreover, polymorphisms in the $M S$ gene have been associated with haematological malignancies [36]. Many studies were conducted to investigate the relationship between substitutions in the $M S$ gene and blood cancers [37-40]. Nevertheless, the results still remain conflicting. 
To our knowledge, the relationship between MPNs and polymorphisms in PROS1, EPCR, PROC, MTHFR, MS genes is not fully understood yet. The main purpose of our study was to evaluate the effects of different SNPs: PROS1 g.66847T>C, EPCR c.4678G >C, EPCR c.6936A>G, $P R O C$ c. $565 \mathrm{C}>\mathrm{T}$, MTHFR c.677C $>\mathrm{T}$, MTHFR c. $1298 \mathrm{~A}>\mathrm{C}, M S$ c. $2756 \mathrm{~A}>\mathrm{G}$ on the risk of thrombosis development and clinical characteristics in patients with PV, ET, and PMF.

\section{MATERIALS AND METHODS}

\section{Editorial Policies and Ethical Considerations}

This study was approved by Kaunas Regional Ethics Committee for Biomedical Research (protocol no. BE-2-9). Signed informed consent forms for participation in the study were obtained from all participants.

\section{Patients}

The study included 88 patients who were diagnosed with ET, PV or PMF between 2000 and 2014 at the Department of Hematology of the Institute of Oncology, the Lithuanian University of Health Sciences, Kaunas, Lithuania. The patient group consisted of men (42\%) and women (58\%), with the mean age of 64.2 years (standard deviation 14,436), the range 27-87 years. Diagnosis was conformed as ET in 45 patients (51.1\%), PV in $36(40.9 \%)$ and PMF in seven (8\%) patients of the studied group. Medical information included the patient's age, sex, history of arterial or venous thrombosis, mean platelet volume, platelet count, mean corpuscular volume. Clinical characteristics are presented in Table I.

\section{Genotyping}

Venous blood samples were collected in vacutainers with EDTA as anticoagulant. Samples were stored at $-20^{\circ} \mathrm{C}$ until further processing. Genomic DNA was extracted from peripheral blood leukocytes using a commercially available DNA extraction kit, according to the instructions provided by the manufacturer (Thermo Fisher Scientific Baltics, Vilnius, 
Lithuania). Genomic variants in all of the cases were detected by employing a polymerase chain reaction - restriction fragment length polymorphism (PCR-RFLP) method. Primer sequences and restriction enzymes used for the detection of PROS1 g.66847T $>\mathrm{C}, E P C R$ c.4678G >C, EPCR c.6936A>G, PROC c.565C > T, MTHFR c.677C > T, MTHFR c.1298A>C, $M S$ c.2756A $>$ G SNPs are presented in Table II. The digested fragments were electrophoresed in a $2 \%$ agarose gel.

\section{Statistical Analysis}

Statistical Package for the Social Sciences (SPSS) 20.0 for Windows was used for the association analysis. To compare percentages the Chi-squared and Fisher's tests were performed. The logistic regression analysis was used to distinguish thrombotic risk factors significantly affecting the possibility of thrombosis and changes in MPV and MCV among the studied patients. Odds ratio (OR) and 95\% confidence intervals $(95 \% \mathrm{CI})$ were calculated from the logistic model. A two-tailed $\mathrm{p}$ value $<0.05$ was taken as statistically significant.

\section{RESULTS}

PROS1 g.66847T>C. The wild 66847TT genotype was observed in 67 of the patients (76.1\%) and the heterozygous 66847TC genotype was found in 21 of the patients (23.9\%) (Table III). No homozygous patients with the 66847CC genotype were detected. Fisher's exact test showed no significant associations between PROS1 g.66847T >C polymorphism and clinical characteristics (Table IV). According to logistic regression analysis, the carriers of the 66847TC genotype had a 0.063 -fold lower chance of developing venous thrombosis $(\mathrm{p}=0.007 ;$ OR $0.063 ; 95 \%$ CI $0.008-0.471)($ Table V).

EPCR c.4678G $>$ C. Out of 88 patients, 31 patients were observed to have the wild 4678GG genotype (35.2\%). The heterozygous 4678GC genotype was found in 43 patients $(48.8 \%)$ and the homozygous mutant 4678CC genotype - 14 (16.0\%) (Table III). Chi-squared association analysis was performed and no significant associations were found between the studied 
polymorphism and clinical characteristics (Table VI). As shown in Table V, carriers of 4678GC genotype were less susceptible to venous thrombosis development $(\mathrm{p}<0.001$; OR 0.226; 95\% CI 0.099-0.513).

EPCR c.6936A>G. After applying the PCR-RFLP method, out of 88 patients, 31 had the wild 6936AA genotype (14.8\%). The heterozygous 6936AG genotype was observed in 60 cases (68.2\%) and the homozygous mutant 6936GG genotype was detected in 15 patients (17.0\%) (Table III). No significant associations were found after performing Chi-squared analysis (Table VII). Logistic regression analysis revealed that carriers of the 6936AG genotype had a lower risk of developing venous ( $\mathrm{p}<0.001$; OR $0.171 ; 95 \%$ CI $0.077-0.381$ ) or arterial thrombosis $(\mathrm{p}=0.026$; OR $0.515 ; 95 \%$ CI $0.287-0.925)$. The results showed that 6936GG genotype was also associated with reduced risk of venous thrombosis development $(\mathrm{p}=0.017$; OR $0.083 ; 95 \%$ CI $0.011-0.641)($ Table V).

PROC c.565C $>$ T. After genotyping our studied group, 44 patients (50\%) were found to have the wild 565CC genotype. The heterozygous 565CT genotype was observed in $25(28.4 \%)$ patients and the homozygous 565TT genotype was found in 19 (21.6\%) (Table III). No significant associations were found after performing Chi-squared analysis (Table VIII). Logistic regression analysis revealed that there is a lower chance of developing venous thrombosis for carriers of the 565CT genotype ( $\mathrm{p}=0.003$; OR $0.158 ; 95 \%$ CI $0.047-0.534$ ) and 565TT genotype $(\mathrm{p}=0.009$; OR $0.067 ; 95 \%$ CI $0.009-0.505)$. Occurrence of thrombosis overall was lower to those who had the 565TT genotype ( $\mathrm{p}=0.048$; OR 0.357 ; 95\% CI 0.129 $-0.992)$. The carriers of 565CT $(\mathrm{p}=0.034$; OR $0.389 ; 95 \%$ CI $0.162-0.931)$ and 565TT $(\mathrm{p}=0.019 ;$ OR $0.267 ; 95 \%$ CI $0.089-0.803)$ genotypes had a lower chance of decreased mean platelet volume (Table V).

MTHFR c.677C $>$ T. After applying the PCR-RFLP method, 45 patients were confirmed to have the wild 677CC genotype (51.1\%), the heterozygous 677CT genotype was observed in 
$37(42.0 \%)$ and the 677TT genotype was confirmed in 6 patients $(6.9 \%)$ of our studied group (Table III). Chi-squared analysis showed no significant associations between the studied polymorphism and clinical characteristics (Table IX). Binary logistic regression analysis revealed that the $667 \mathrm{CT}$ genotype was associated with the lower the risk of venous thrombosis development ( $\mathrm{p}=0.001$; OR 0.214 ; 95\% CI $0.089-0.518)$ (Table V).

MTHFR c.1298A >C. The wild 1298AA genotype was discovered in 37 (42\%) patients, the heterozygous 1298AC genotype was found in 34 (38.6\%) patients and the homozygous CC genotype - $17(19.4 \%)$ patients (Table III). Chi-squared analysis showed the significant association between the studied polymorphism and venous thrombosis $\left(\chi^{2}\right.$ $(2, \mathrm{~N}=88)=7.278, \mathrm{p}=0.019)($ Table $\mathrm{X})$.

$M S$ c.2756A>G. Out of 88 patients with myeloproliferative disorders, 54 (51.4\%) patients were confirmed as carriers of the wild 2756AA genotype, heterozygous 2756AG genotype was observed in $30(34.1 \%)$ patients and the homozygous $2756 \mathrm{GG}$ - in $4(4.5 \%)$ patients (Table III). Chi-squared analysis revealed no associations (Table XI). Logistic regression analysis showed that carriers of the $2675 \mathrm{AG}$ genotype had a lower risk of developing venous thrombosis $(\mathrm{p}=0.001 ;$ OR $0.091 ; 95 \%$ CI $0.021-0.387)$. These results are summarised in Table V.

\section{DISCUSSION}

The selected SNPs for this study have a tendency to occur in patients with $\mathrm{Ph}$ myeloproliferative neoplasms, but their significance to thrombosis development is not fully evaluated yet. The objective of this study was to assess the importance of PROSI g.66847T >C, EPCR c.4678G >C, EPCR c.6936A >G, PROC c.565C > T, MTHFR c.677C > T, MTHFR c. $1298 \mathrm{~A}>\mathrm{C}, M S$ c. $2756 \mathrm{~A}>\mathrm{G}$ polymorphisms to the development of thrombotic events and clinical characteristics related to them. 
Polymorphisms in PROC (coding for protein C) and PROS1 (coding for protein S) can be the cause of a dysfunctional component in the coagulation cascade and could be associated with various thrombotic events. In this study, it was observed that a nucleotide change from $\mathrm{T}$ to $\mathrm{C}$ in the 66847 position of PROS1 gene can lead to lower probability of developing venous thrombosis. Although, in a study, performed by Reiner et al., there was no evidence of associations between the studied polymorphism and incidence of cardiovascular diseases [45]. Apart from this study there are no more researches performed with this SNP and hematological complications. This information suggests that the polymorphism is not widely studied and needs more investigation, hence, there are signs of possible importance. Protein $\mathrm{C}$, which is coded by PROC gene, is a key component of the coagulation cascade and it is known that the lack of protein Ccause a predisposition to venous thrombosis. Tang and his colleagues reported that the carriers of 565CT genotype had an 8.8-fold increased risk of venous thrombosis in Chinese population with hereditary protein $\mathrm{C}$ deficiency [43]. This study contradicts our results, since our data suggests that the 565CT or 565TT genotypes can be considered as a protective factors against venous thrombosis. This incongruity could be caused by mismatched studied group ethnicity, since there was a report by Yin et al. that Asian populations have higher rates of venous thromboembolism $(4-31.76 \%)$ compared to the general population $(0,29-4 \%)$ and that the $P R O C$ c.565C $>\mathrm{T}$ SNP has a higher frequency of occurrence in the Chinese population, compared to populations in the west [46]. Another predictor with diagnostic importance is mean platelet volume which increases with the overproduction of thrombocytes [47]. Our study revealed that patients harboring the 565CT and 565TT genotypes may have a lower risk of decrease in MPV. In a study performed by Ayer et al. it was reported that there are no significant associations between mean platelet volume and thromboembolic events in ET $(\mathrm{p}=0.483)$ and PV $(\mathrm{p}=0.221)$ groups [48]. This suggests that MPV may not contribute to thrombotic events in myeloproliferative disorders. 
It was previously reported that the $E P C R$ c. $4678 \mathrm{G}>\mathrm{C}$ SNP was identified as a protective factor against venous thrombosis because of it's association with high levels of circulating activated protein C (APC). The data in Medina et al. study suggests that carriers of FV Leiden with the 4678CC genotype may have a lower risk of venous thrombosis development and may experience first thrombotic events significantly later than those with 4678GG or 4678GC genotypes [26]. Karabjyjk et al. also reported that this polymorphism may offer protection against thrombosis, where out of 111 patients 79 were observed to have the 4678GC genotype and 19 patients had the 4678GG genotype [49]. This information agrees with our findings, although the obtained results that another studied polymorphism $-E P C R$ c.6936A $>\mathrm{G}-$ could be considered as a protective factor against thrombosis are inconsistent with the previous researches. Besbes et al. also reported a significant association between this polymorphism and thrombotic events, although they reported different findings. After genotyping 110 patients with hematological complications they calculated that the 6936AG genotype may increase the risk of thrombosis, compared to the 6936AA genotype [50]. That was in agreement with a newer study performed by Zoheir et al. where it was established that the $\mathrm{G}$ allele increases the risk of thrombosis by two-fold (studied patient group consisted of 90 people) [51]. This difference could be explained by the fact that these genotypes showed different distribution among different studied group ethnicity.

Higher levels of homocysteine are thought to play an important role in the occurrence of venous thrombosis [52]. A common genetic variant that affects homocysteine levels exists in the gene that encodes the methylenetetrahydrofolate reductase (MTHFR) enzyme. This polymorphism, in which a substitution from $\mathrm{C}$ to $\mathrm{T}$ occurs at position 677 , induces a change of alanine to valine and impaired enzyme activity [53]. Although, its correlation with venous thrombosis remains controversial. In this study the only significant association between the 677CT genotype and lower risk of VT occurrence was found. 
There are a lot of studies with inconsistent results regarding this polymorphism. Two studies carried out in Iranian and Northwestern Greece populations showed no significant associations between the MTHFR c.677C > T polymorphism and venous thrombosis [54, 55]. A meta-analysis, performed by M. den Heijer and colleagues, showed that the 677TT genotype relates with $20 \%$ increased risk of VT. Also, a difference between increased risk of thrombosis in studies carried out in Europe and North America (lower risk in Europe) was noticed, although not significant, which may be explained by dietary differences [56]. Another polymorphism in this gene - c.1298A $>$ C. According to our study this SNP seems to be associated with venous thrombosis. Akar et al. research revealed that this polymorphism alone does not contribute to thrombotic events, although they found out that carriers of MTHFR c.677C>T and c.1298A >C in double heterozygous or homozygous states have an impact on higher thrombotic risk in Turkish population [57]. This information partially could explain the controversial results published by other authors regarding these SNPs but further investigations need to be done to establish clear prognostic value.

One of the other factors that may predispose to thrombosis is the nucleotide change from A to $\mathrm{G}$ in the 2756 position of the methionine synthase $(M S)$ gene which leads to changes in the enzyme activity and increased homocysteine levels [58]. From our data, it is apparent that the $2756 \mathrm{AG}$ genotype may be considered as a protective factor against venous thrombosis. That was in agreement with the results of Z. Yates et al. study, which reported that the $\mathrm{G}$ allele may offer significant protection against thromboembolic events $(\mathrm{OR}=0.39, \mathrm{p}=0.0065)$ [59]. There is convincing evidence that the $M S \mathrm{c} .2756 \mathrm{~A}>\mathrm{G}$ and MTHFR c.677C $>$ T polymorphisms could provide possible health benefits.

As interesting as these findings are, more research into these polymorphisms needs to be performed, since there are many conflicting results published regarding the complexity of 
the possible interactions between these gene variants and predisposition to thrombotic events. This kind of research into possible biomarkers for thrombosis in myeloproliferative patients is the first in Lithuania and could lead to the new insights when determining disease treatment and outcomes. 


\section{REFERENCES}

1. Harrison C. Myeloproliferative disorders. Med. 2004; 32(6): 58-60.

2. Dambrauskienė R, Gerbutavičius R, Ugenskienė R. et al. Genetic polymorphisms of hemostatic factors and thrombotic risk in non BCR-ABL myeloproliferative neoplasms: A pilot study. Balk J Med Gen. 2017; 20(1): 35-42.

3. Abdel-Wahab OI, Levine RL. Primary myelofibrosis: update on definition, pathogenesis, and treatment. Annu Rev Med. 2009; 60(1): 233-245.

4. Cervantes F. Management of essential thrombocythemia. Hematology (Am Soc Hematol Educ Program). 2011; 2011(1): 215-221.

5. Spivak JL. Polycythemia vera: myths, mechanisms, and management. Blood. 2002; 100(13): 4272-4290.

6. Berglund S, Zettervall O. Incidence of polycythemia vera in a defined population. Eur J Haematol. 1992; 48(1): 20-26.

7. Marchioli R, Finazzi G, Landolfi R, et al. Vascular and neoplastic risk in a large cohort of patients with polycythemia vera. J Clin Oncol. 2005; 23(10): 2224-2232.

8. Carobbio A, Thiele J, Passamonti F, et al. Risk factors for arterial and venous thrombosis in WHO-defined essential thrombocythemia: an international study of 891 patients. Blood. 2011; 117(22): 5857-5859.

9. Barbui T, Carobbio A, Cervantes F, et al. Thrombosis in primary myelofibrosis: Incidence and risk factors. Blood. 2010; 115(4): 778-782.

10. Passamonti F, Rumi E, Pungolino E, et al. Life expectancy and prognostic factors for survival in patients with polycythemia vera and essential thrombocythemia. Am J Med. 2004; 117(10): 755-761.

11. Watson KV, Key N. Vascular complications of essential thrombocythaemia: A link to cardiovascular risk factors. Br J Haematol. 1993; 83(2): 198-203. 
12. Barbui T, Thiele J, Passamonti F, et al. Survival and disease progression in essential thrombocythemia are significantly influenced by accurate morphologic diagnosis: An international study. J Clin. Oncol. 2011; 29(23): 3179-3184.

13. Campbell PJ, MacLean C, Beer PA, et al. Correlation of blood counts with vascular complications in essential thrombocythemia: analysis of the prospective PT1 cohort. Blood. 2012 Aug 16; 120(7): 1409-1411.

14. Dahlback B, Villoutreix BO. The anticoagulant protein C pathway. FEBS Lett. 2005; 579: 3310-3316.

15. Mosnier LO, Zlokovic BV, Griffin JH. The cytoprotective protein C pathway. Blood. 2007; 109: 3161-3172.

16. Kallel C, Cohen W, Saut N, et al. Association of soluble endothelial protein C receptor plasma levels and PROCR rs867186 with cardiovascular risk factors and cardiovascular events in coronary artery disease patients: the Athero Gene study. BMC Med Genet. 2012; 8(13): 103.

17. Reiner AP, Carty CL, Jenny NS, et al. PROC, PROCR, and PROS1 polymorphisms, plasma anticoagulant phenotypes, and risk of cardiovascular disease and mortality in older adults: the Cardiovascular Health Study. J Thromb Haemost. 2008; 6(10): 16251632.

18. Pritchard AM, Hendrix PW, Paidas MJ. Hereditary thrombophilia and recurrent pregnancy loss. Clin Obstet Gynecol. 2016; 59(3): 487-497.

19. Schild RL, Lobb MO, Voke JM. Hereditary thrombophilia in a family with three independent protein $\mathrm{S}$ and $\mathrm{C}$ mutations. A cause of adverse perinatal outcome. Eur $\mathrm{J}$ Obstet Gynecol Reprod Biol. 1998; 80(2): 283-285.

20. Wu, D, Zhong, Z, Chen, Y, et al. Analysis of PROC and PROS1 single nucleotide polymorphisms in a thrombophilia family. Clin Respir J. 2019; 13: 530-537. 
21. Medina P, Bonet E, Navarro S, et al. Effects of oral anticoagulant therapy and haplotype 1 of the endothelial protein $\mathrm{C}$ receptor gene on activated protein $\mathrm{C}$ levels. Thromb Haemost. 2012 Mar; 107(3): 448-457.

22. Stearns-Kurosawa DJ, Kurosawa S, Mollica JS, et al. The endothelial cell protein C receptor augments protein $\mathrm{C}$ activation by the thrombin-thrombomodulin complex. Proc Natl Acad Sci USA. 1996; 93(19): 1021-1026.

23. Navarro S, Bonet E, Estelle's A, et al. The endothelial cell protein $\mathrm{C}$ receptor: its role in thrombosis. Thromb Res. 2011; 128(5): 410-416.

24. Centelles MN, Puy C, Lo'pez-Sagaseta J, Fukudome K, Montes R, Hermida J. Blocking endothelial protein $\mathrm{C}$ receptor (EPCR) accelerates thrombus development in vivo. Thromb Haemost. 2010; 103: 1239-1244.

25. Medina P, Navarro S, Bonet E, et al. Functional analysis of two haplotypes of the human endothelial protein C receptor gene. Arterioscler Thromb Vasc Biol. 2014; 34:684-690

26. Medina P, Navarro S, Estelle's A, Vaya' A, Bertina RM, España F. Influence of the 4600A/G and 4678G/C polymorphisms in the endothelial protein C receptor (EPCR) gene on the risk of venous thromboembolism in carriers of factor V Leiden. Thromb Haemost. 2005; 94(2): 389-394.

27. Saposnik B, Reny JL, Gaussem P, Emmerich J, Aiach M, Gandrille S. A haplotype of the EPCR gene is associated with increased plasma levels of sEPCR and is a candidate risk factor for thrombosis. Blood. 2004; 103(4): 1311-1318.

28. Jiasheng X, Kexin L, Weimin Z. Relationship between genetic polymorphism of MTHFR C677T and lower extremities deep venous thrombosis, Hematology. 2019; 24(1): 108111. 
29. Gaughan DJ, Kluijtmans LAJ, Barbaux S, et al. The methionine synthase reductase (MTRR) A66G polymorphism is a novel genetic determinant of plasma homocysteine concentrations. Atherosclerosis. 2001; 157: 451-456.

30. Yamada K, Gravel RA, Toraya T, Matthews RG. Human methionine synthase reductase is a molecular chaperone for human methionine synthase. Proc Natl Acad Sci USA. 2006; 103: 9476-9481.

31. El-Ghonemy MS, El Sharawy S, Fahmi MW, El-Ashwah S, Denewer M, El-Baiomy MA. Thrombophilic Risk of Factor V Leiden, Prothrombin G20210A, MTHFR, and Calreticulin Mutations in Essential Thrombocythemia Egyptian Patients. Adv Hematol. 2020; 2020: 7695129.

32. Zara-Lopes T, Silva Galbiatti-Dias AL, Urbanin Castanhole-Nunes MM, et al. Polymorphisms in MTHFR, MTR, RFC1 and CßS genes involved in folate metabolism and thyroid cancer: a case-control study. Arch Med Sci. 2019; 15(2): 522-530.

33. Simone B, De Stefano V, Leoncini E, et al. Risk of venous thromboembolism associated with single and combined effects of Factor V Leiden, Prothrombin 20210A and Methylenetethraydrofolate reductase C677T: a meta-analysis involving over 11,000 cases and 21,000 controls. Eur J Epidemiol. 2013; 28(8): 621-647.

34. Trifa AP, Cucuianu A, Popp RA, Costache RM, Coadă CA, Sarca AD, Urian LG, Dima D, Petrov L, Farcaş MF, Militaru MS, Pop IV. Analysis of the MTHFR (methylenetetrahydrofolate reductase) $677 \mathrm{C}>\mathrm{T}$ and $1298 \mathrm{~A}>\mathrm{C}$ polymorphisms in $\mathrm{BCR}-$ ABL-negative myeloproliferative neoplasms. Int J Lab Hematol. 2013 Feb; 35(1): e9-12.

35. Hosseini, S., Kalantar, E., Hosseini, M.S. et al. Genetic risk factors in patients with deep venous thrombosis, a retrospective case control study on Iranian population. Thrombosis J. 2015; 13: 35 . 
36. Bai Y, Kwateng Drokow E, Waqas Ahmed HA, et al. The relationship between methionine synthase rs 1805087 polymorphism and hematological cancers risk. Future Oncol. 2020; 16(28): 2219-2233.

37. Wu B, Liu K, Yang JP, Hu Y, Zhang J, He JX. The association between methionine synthase A2756G polymorphism and hematological cancer: A meta-analysis. Medicine (Baltimore). 2017; 96(48): e7469.

38. Nikbakht M, MalekZadeh K, Kumar Jha A, et al. Polymorphisms of MTHFR and MTR genes are not related to susceptibility to childhood ALL in North India. Exp Oncol. 2012; 34: 43-438.

39. Ruiz-Cosano J, Torres-Moreno D, Conesa-Zamora P. Influence of polymorphisms in ERCC5, XPA and MTR DNA repair and synthesis genes in B-cell lymphoma risk. A case-control study in Spanish population. J BUON. 2013; 18: 486-490.

40. Lima CS, Ortega MM, Ozelo MC, et al. Polymorphisms of methylenetetrahydrofolate reductase (MTHFR), methionine synthase (MTR), methionine synthase reductase (MTRR), and thymidylate synthase (TYMS) in multiple myeloma risk. Leuk Res. 2008; 32: 401-405.

41. Qin J, Li L, Zhang D, et al. Analysis of receptor tyrosine kinase genetics identifies two novel risk loci in GAS6 and PROS1 in Behçet's disease. Sci Rep. 2016; 6(1): 26662.

42. Sesin CA, Yin X, Esmon CT, Buyon JP, Clancy RM. Shedding of endothelial protein C receptor contributes to vasculopathy and renal injury in lupus: in vivo and in vitro evidence. Kidney Int. 2005; 68(1): 110-120.

43. Tang L, Guo T, Yang R, et al. Genetic background analysis of protein C deficiency demonstrates a recurrent mutation associated with venous thrombosis in Chinese population. PLoS One. 2012; 7(4): e35773. 
44. Vahid P, Farnaz R, Zaker F, Farzaneh A, Parisa R. Methylenetetrahydrofolate Reductase Gene Polymorphisms and Risk of Myeloid Leukemia. Lab Med. 2010; 41(8): 490-494.

45. Shekari M, Sobti RC, Kordi Tamandani DM, Suri V. Impact of methylenetetrahydrofolate reductase (MTHFR) codon (677) and methionine synthase (MS) codon (2756) on risk of cervical carcinogenesis in North Indian population. Arch Gynecol Obstet. 2008; 278(6): 517-524.

46. Yin T, Miyata T. Dysfunction of protein C anticoagulant system, main genetic risk factor for venous thromboembolism in northeast Asians. J Thromb Thrombolysis. 2014; 37(1): $56-65$.

47. Trowbridge EA, Martin JF. The platelet volume distribution: a signature of the prethrombotic state in coronary heart disease? Thromb Haemost. 1987; 58(2): 714-717.

48. Ayer M, Menken İ, Yamak M, Ayer FA, Kırkızlar O, Burak Aktuğlu M. The Impact of Mean Platelet Volume (MPV) and JAK-2 Mutation on Thrombosis in Chronic Myeloproliferative Diseases. Indian J Hematol Blood Transfus. 2017; 33(2): 181-187.

49. Karabıyık A, Yılmaz E, Eğin Y, Akar N. The effects of endothelial protein C receptor gene polymorphisms on sEPCR levels in venous thrombotic patients. Turk J Haematol. 2012; 29(1): 55-62.

50. Besbes S, Althawadi H, Alfarsi H, et al. Endothelial protein C receptor gene 6936A/G single-nucleotide polymorphism as a possible biomarker of thrombotic risk in acute myeloid leukemia. Mol Clin Oncol. 2015; 3(6): 1280-1284.

51. Zoheir N, Eldanasouri N, Abdel-Aal AA, Hosny KA, Abdel-Ghany WM. Endothelial cell protein C receptor gene 6936A/G and 4678G/C polymorphisms as risk factors for deep venous thrombosis. Blood Coagul Fibrinolysis. 2016; 27(3): 259-265. 
52. Smith GD, Ebrahim S. 'Mendelian randomization': can genetic epidemiology contribute to understanding environmental determinants of disease? Int J Epidemiol. 2003; 32(1): 122.

53. Frosst P, Blom HJ, Milos R, et al. A candidate genetic risk factor for vascular disease: a common mutation in methylenetetrahydrofolate reductase. Nat Genet. 1995; 10(1): 111113.

54. Soltanpour M, Soheili Z, Pourfathollah A, et al. The association between common C677T mutation in methylenetetrahydrofolate reductase gene and the risk of venous thrombosis in an Iranian oopulation. Lab Med. 2008; 39(2): 97-100.

55. Zalavras CG, Giotopoulou S, Dokou E, et al. Lack of association between the C677T mutation in the 5,10-methylenetetrahydrofolate reductase gene and venous thromboembolism in Northwestern Greece. Int Angiol. 2002; 21(3): 268-271.

56. Heijer MD, Lewington S, Clarke R. Homocysteine, MTHFR and risk of venous thrombosis: a meta-analysis of published epidemiological studies. J Thromb Haemost. 2005; 3(2): 292-299.

57. Akar N, Akar E, Akçay R, Avcu F, Yalcin A, Cin S. Effect of methylenetetrahydrofolate reductase 677 C-T, 1298 A-C, and 1317 T-C on factor V 1691 mutation in Turkish deep vein thrombosis patients. Thromb Res. 2000; 97(3): 163-167.

58. Rosendaal FR. Venous thrombosis: prevalence and interaction of risk factors. Haemostasis. 1999; 29(1 Suppl S1): 1-9.

59. Yates Z, Lucock M. Methionine synthase polymorphism A2756G is associated with susceptibility for thromboembolic events and altered B vitamin/thiol metabolism. Haematologica. 2002; 87(7): 751-756. 
Table I. Clinical characteristics.

\begin{tabular}{|l|l|}
\hline Characteristics & Patients (n=88) \\
\hline Age: mean (SD) & $64.2(14.44)$ \\
\hline Males: $\mathrm{n}(\%)$ & $37(42)$ \\
Females: $\mathrm{n}(\%)$ & $51(58)$ \\
\hline Arterial thrombosis: $\mathrm{n}(\%)$ & $29(33)$ \\
\hline Venous thrombosis: $\mathrm{n}(\%)$ & $10(11.4)$ \\
\hline Incidence of thrombosis: $\mathrm{n}(\%)$ & $39(44)$ \\
\hline Decreased mean platelet volume: $\mathrm{n}(\%)$ & $22(25)$ \\
\hline $\begin{array}{l}\text { Normal mean platelet volume: } \mathrm{n}(\%) \\
\text { Increased mean platelet volume: } \mathrm{n}(\%)\end{array}$ & $22(25)$ \\
\hline Decreased mean corpuscular volume: $\mathrm{n}(\%)$ & $22(25)$ \\
Normal mean corpuscular volume: $\mathrm{n}(\%)$ & $54(61.3)$ \\
Increased mean corpuscular volume: $\mathrm{n}(\%)$ & $3(3.4)$ \\
\hline
\end{tabular}

Note: $\mathrm{n}$, number of individuals; SD, standard deviation. 
Table II. Primer sequences and restriction enzymes used for genotyping, length of DNA fragments after applying the PCR-RFLP method.

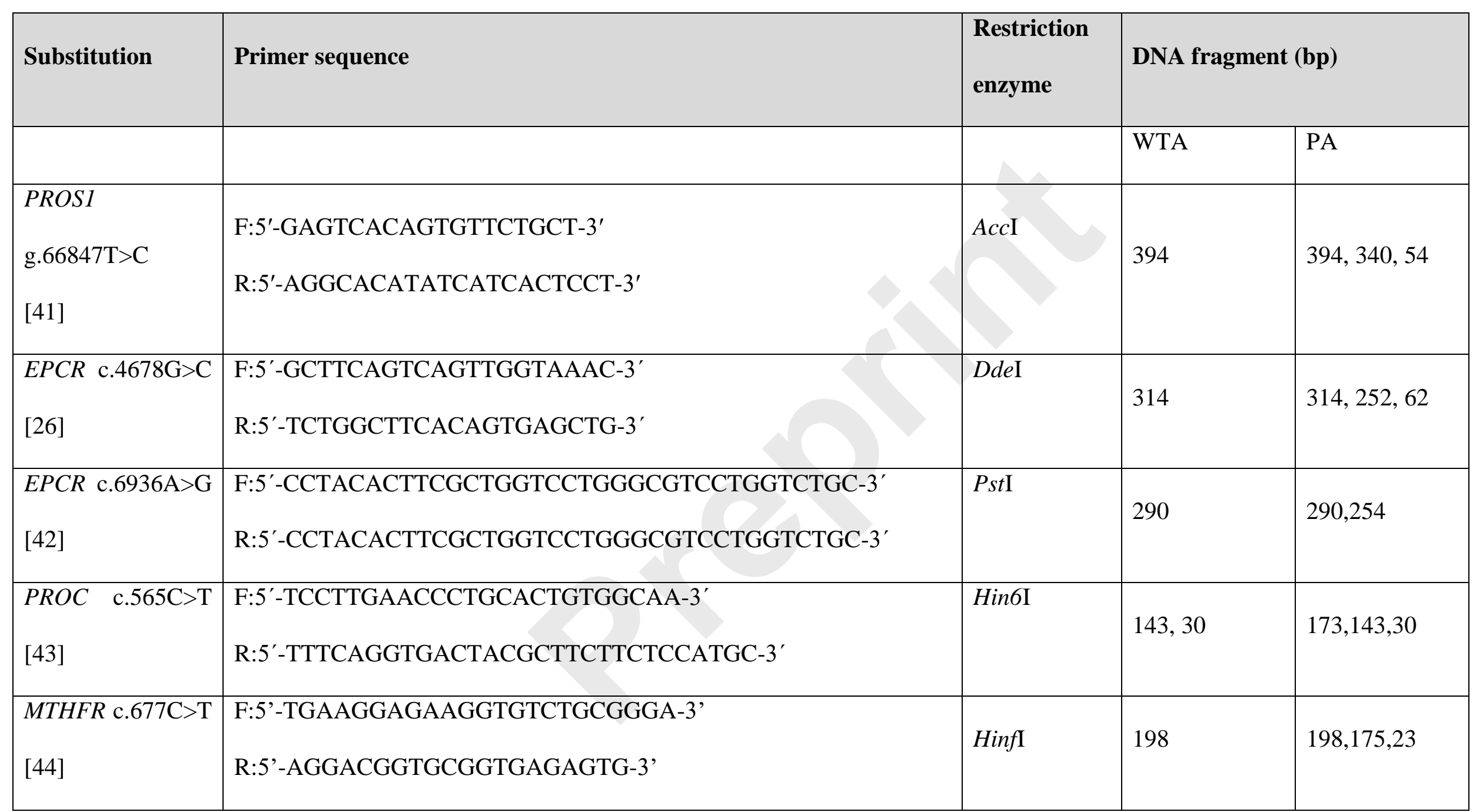




\begin{tabular}{|l|l|l|l|}
\hline $\begin{array}{l}\text { MTHFR } \\
\text { c.1298A>C }\end{array}$ & $\left.\begin{array}{l}\text { F:5'-GCAAGTCCCCCAAGGAGG-3' } \\
\text { R:5'-GGTCCCCACTTCCAGCATC-3' }\end{array}\right]$ & MboII & $79,37,29$ \\
\hline MS c.2756A>G & F:5'-TGTTCCAGACAGTTAGATGAAAATC-3' & $108,79,37,29$ \\
{$[17]$} & R:5'-GATCCAAAGCCTTTTACACTCCTC-3' & HaeIII & 211 \\
\hline
\end{tabular}

Note: F, Forward; R, Reverse; WTA, Wild Type Allele; PA, Polymorphic Allele; bp, base pair. 
Table III. Genotype frequencies.

\begin{tabular}{|c|c|c|c|c|c|c|c|c|c|c|c|c|}
\hline Polymorphism & \multicolumn{3}{|c|}{ PROS1 g.66847T >C } & \multicolumn{3}{|c|}{$E P C R$ c. $4678 \mathrm{G}>\mathrm{C}$} & \multicolumn{3}{|c|}{$E P C R$ с.6936A $>\mathrm{G}$} & \multicolumn{3}{|c|}{ PROC c.565 C>T } \\
\hline Genotype & TT & $\mathrm{TC}$ & $\mathrm{CC}$ & GG & $\mathrm{GC}$ & $\mathrm{CC}$ & AA & $\mathrm{AG}$ & GG & $\mathrm{CC}$ & $\mathrm{CT}$ & $\mathrm{TT}$ \\
\hline $\begin{array}{l}\text { n } \\
(\%)\end{array}$ & $\begin{array}{l}67 \\
(76.1)\end{array}$ & $\begin{array}{l}21 \\
(23.9)\end{array}$ & $\begin{array}{l}0 \\
0\end{array}$ & $\begin{array}{l}31 \\
(35.2)\end{array}$ & $\begin{array}{l}43 \\
(48.8)\end{array}$ & $\begin{array}{l}14 \\
(16.0)\end{array}$ & $\begin{array}{l}13 \\
(14.8)\end{array}$ & $\begin{array}{l}60 \\
(68.2)\end{array}$ & $\begin{array}{l}15 \\
(17.0)\end{array}$ & $\begin{array}{l}44 \\
(50.0)\end{array}$ & $\begin{array}{l}25 \\
(28.4)\end{array}$ & $\begin{array}{l}19 \\
(21.6)\end{array}$ \\
\hline Polymorphism & \multicolumn{3}{|c|}{ MTHFR c.677C >T } & \multicolumn{3}{|c|}{ MTHFR c. $1298 \mathrm{~A}>\mathrm{C}$} & \multicolumn{3}{|c|}{$M S$ c. $2756 \mathrm{~A}>\mathrm{G}$} & & & \\
\hline Genotype & $\mathrm{CC}$ & $\mathrm{CT}$ & TT & AA & $\mathrm{AC}$ & $\mathrm{CC}$ & AA & $\mathrm{AG}$ & GG & & & \\
\hline $\begin{array}{l}\text { n } \\
(\%)\end{array}$ & $\begin{array}{l}45 \\
(51.1)\end{array}$ & $\begin{array}{l}37 \\
(42.0)\end{array}$ & $\begin{array}{l}6 \\
(6.9)\end{array}$ & $\begin{array}{l}37 \\
(42.0)\end{array}$ & $\begin{array}{l}34 \\
(38.6)\end{array}$ & $\begin{array}{l}17 \\
(19.4)\end{array}$ & $\begin{array}{l}54 \\
(61.4)\end{array}$ & $\begin{array}{l}30 \\
(34.1)\end{array}$ & $\begin{array}{l}4 \\
(4.5)\end{array}$ & & & \\
\hline
\end{tabular}


Table IV. PROS1 g.66847T>C genotype distribution among clinical characteristics.

\begin{tabular}{|c|c|c|c|c|}
\hline \multirow[t]{3}{*}{ Characteristics } & \multicolumn{3}{|c|}{ PROS1 g.66847T $>C$} & \multirow[t]{3}{*}{$p$ value } \\
\hline & TT & $\mathrm{TC}$ & $\mathrm{CC}$ & \\
\hline & $\mathrm{N}(\%)$ & $\mathrm{N}(\%)$ & $\mathrm{N}(\%)$ & \\
\hline \multicolumn{5}{|l|}{$\begin{array}{l}\text { Venous } \\
\text { thrombosis }\end{array}$} \\
\hline- & $46(74.2)$ & $16(25.8)$ & 0 & \multirow{2}{*}{0.434} \\
\hline+ & $9(90.0)$ & $1(10.0)$ & 0 & \\
\hline \multicolumn{5}{|l|}{$\begin{array}{l}\text { Arterial } \\
\text { thrombosis }\end{array}$} \\
\hline- & $34(72.3)$ & $13(27.7)$ & 0 & \multirow[t]{2}{*}{0.591} \\
\hline+ & $23(79.3)$ & $6(20.7)$ & 0 & \\
\hline \multicolumn{5}{|c|}{$\begin{array}{l}\text { Incidence of } \\
\text { thrombosis }\end{array}$} \\
\hline- & $38(73.1)$ & $14(26.9)$ & 0 & \multirow[t]{2}{*}{0.458} \\
\hline+ & $29(80.6)$ & $7(19.4)$ & 0 & \\
\hline
\end{tabular}




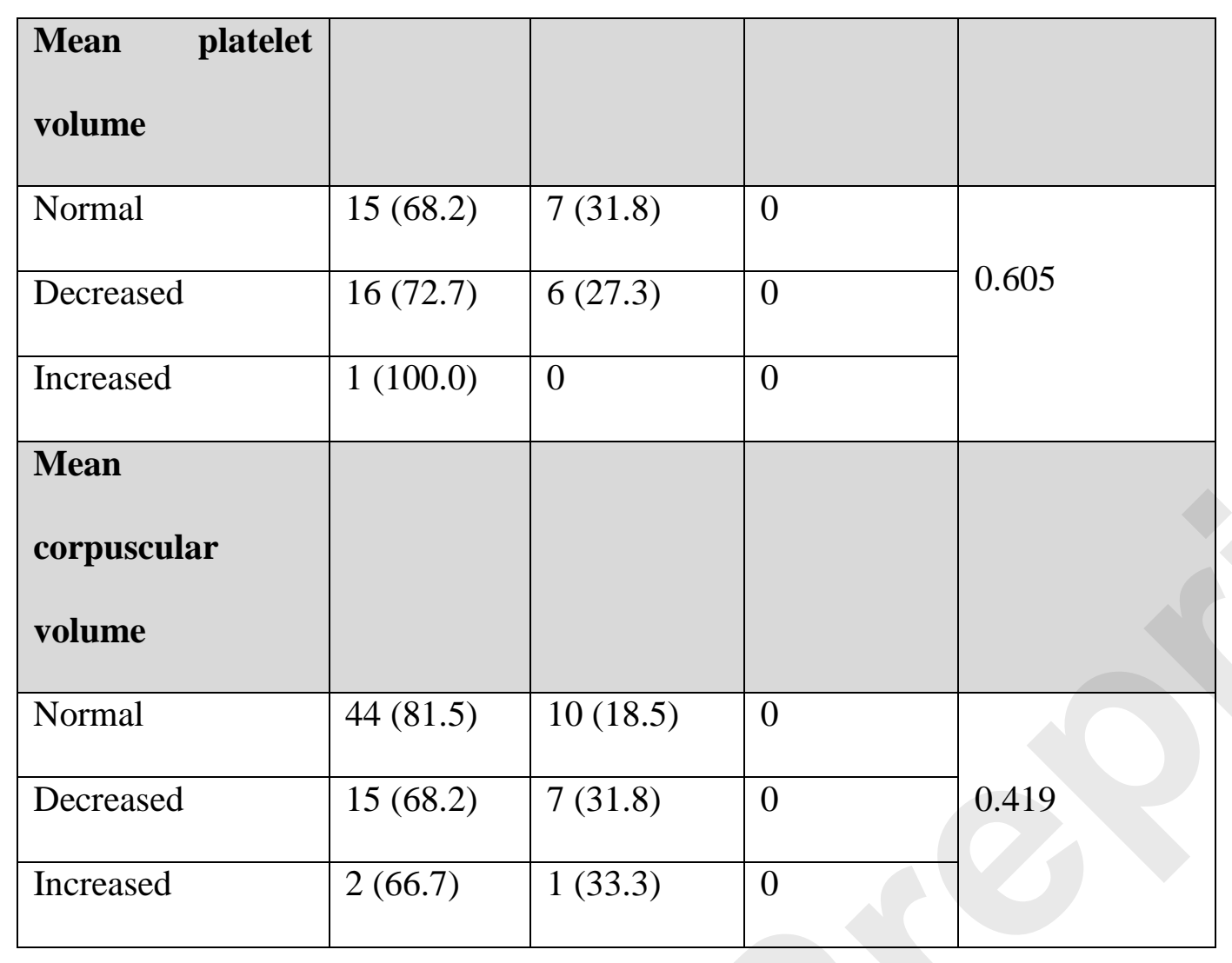


Table V. Binary logistic regression analysis.

\begin{tabular}{|c|c|c|c|c|c|c|}
\hline Polymorphism & Genotype & Clinical characteristic & $\mathbf{B}$ & OR & $p$ value & 95\% CI-OR \\
\hline $\begin{array}{l}\text { PROS1 } \\
\text { g.66847T >C }\end{array}$ & $\mathrm{TC}$ & Venous thrombosis & $\begin{array}{l}- \\
2.773\end{array}$ & 0.063 & 0.007 & $0.008-0.471$ \\
\hline $\begin{array}{l}E P C R \\
\text { c. } 4678 \mathrm{G}>\mathrm{C}\end{array}$ & GC & Venous thrombosis & $\begin{array}{l}- \\
1.488\end{array}$ & 0.226 & $<0.001$ & $0.099-0.513$ \\
\hline \multirow{3}{*}{$\begin{array}{l}E P C R \\
\text { c.6936A>G }\end{array}$} & $\mathrm{AG}$ & \multirow{2}{*}{ Venous thrombosis } & $\begin{array}{l}- \\
1.768\end{array}$ & 0.171 & $<0.001$ & $0.077-0.381$ \\
\hline & GG & & 2.485 & 0.083 & 0.017 & $0.011-0.641$ \\
\hline & AG & Arterial thrombosis & 0.663 & 0.515 & 0.026 & $0.287-0.925$ \\
\hline \multirow{2}{*}{$\begin{array}{l}\text { PROC } \\
\text { c. } 565 \mathrm{C}>\mathrm{T}\end{array}$} & $\mathrm{CT}$ & \multirow{2}{*}{ Venous thrombosis } & 1.846 & 0.158 & 0.003 & $0.047-0.534$ \\
\hline & TT & & 2.078 & 0.067 & 0.009 & $0.009-0.505$ \\
\hline
\end{tabular}




\begin{tabular}{|c|c|c|c|c|c|c|}
\hline & $\mathrm{TT}$ & Incidence of thrombosis & $\begin{array}{l}- \\
1.030\end{array}$ & 0.357 & 0.048 & $0.129-0.992$ \\
\hline & $\mathrm{CT}$ & Decreased mean platelet & $\begin{array}{l}- \\
0.944\end{array}$ & 0.389 & 0.034 & $0.162-0.931$ \\
\hline & TT & volume & $\begin{array}{l}- \\
1.322\end{array}$ & 0.267 & 0.019 & $0.089-0.803$ \\
\hline $\begin{array}{l}\text { MTHFR } \\
\text { c. } 677 \mathrm{C}>\mathrm{T}\end{array}$ & $\mathrm{CT}$ & Venous thrombosis & $\begin{array}{l}- \\
1.540\end{array}$ & 0.214 & 0.001 & $0.089-0.518$ \\
\hline$M S$ c. $2756 \mathrm{~A}>\mathrm{G}$ & $\mathrm{AG}$ & Venous thrombosis & $\begin{array}{l}- \\
2.398\end{array}$ & 0.091 & 0.001 & $0.021-0.387$ \\
\hline
\end{tabular}

Note: B, regression coefficient; OR, odds ratio; 95\% CI, confidence interval. 
Table VI. EPCR c.4678G>C genotype distribution among clinical characteristics.

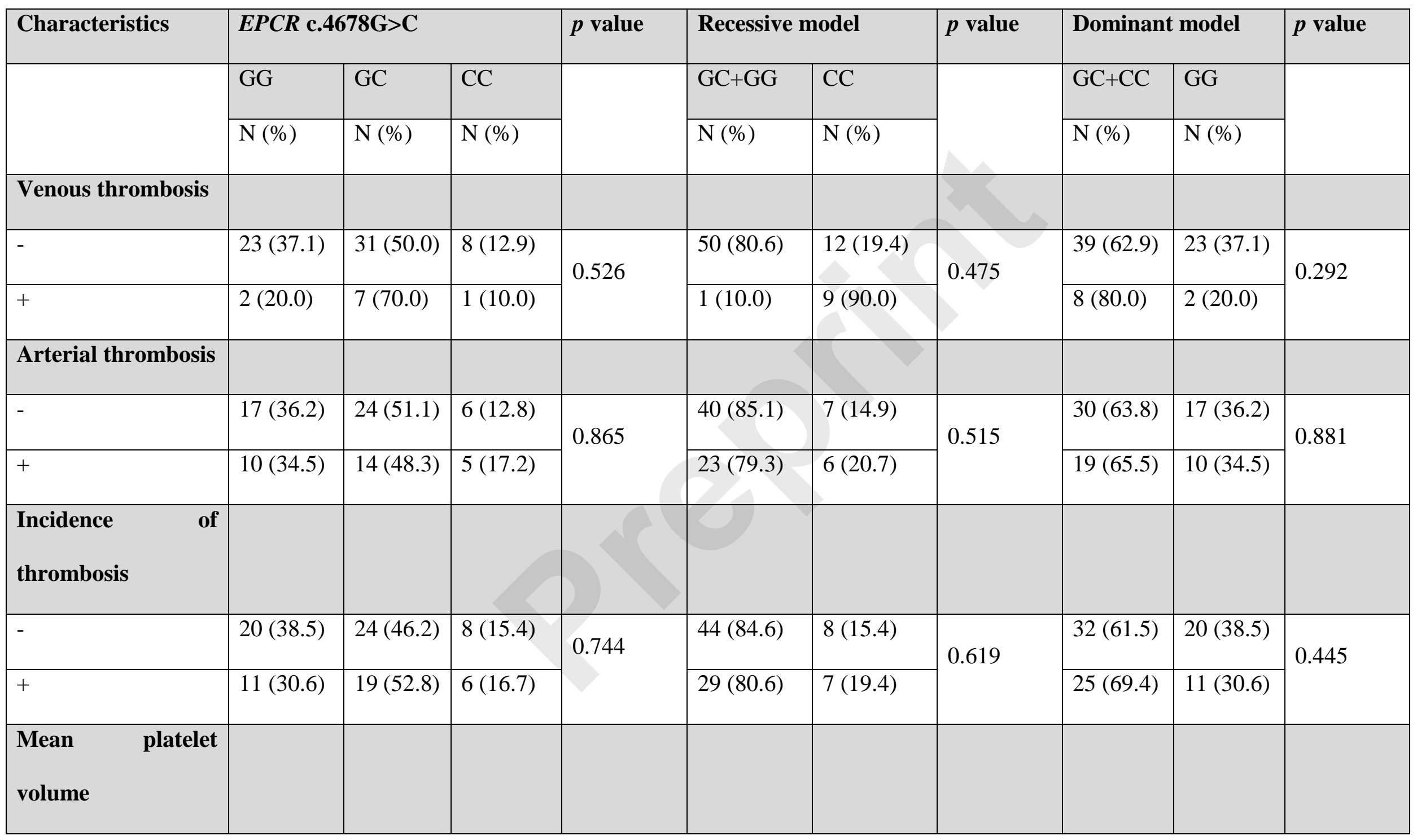




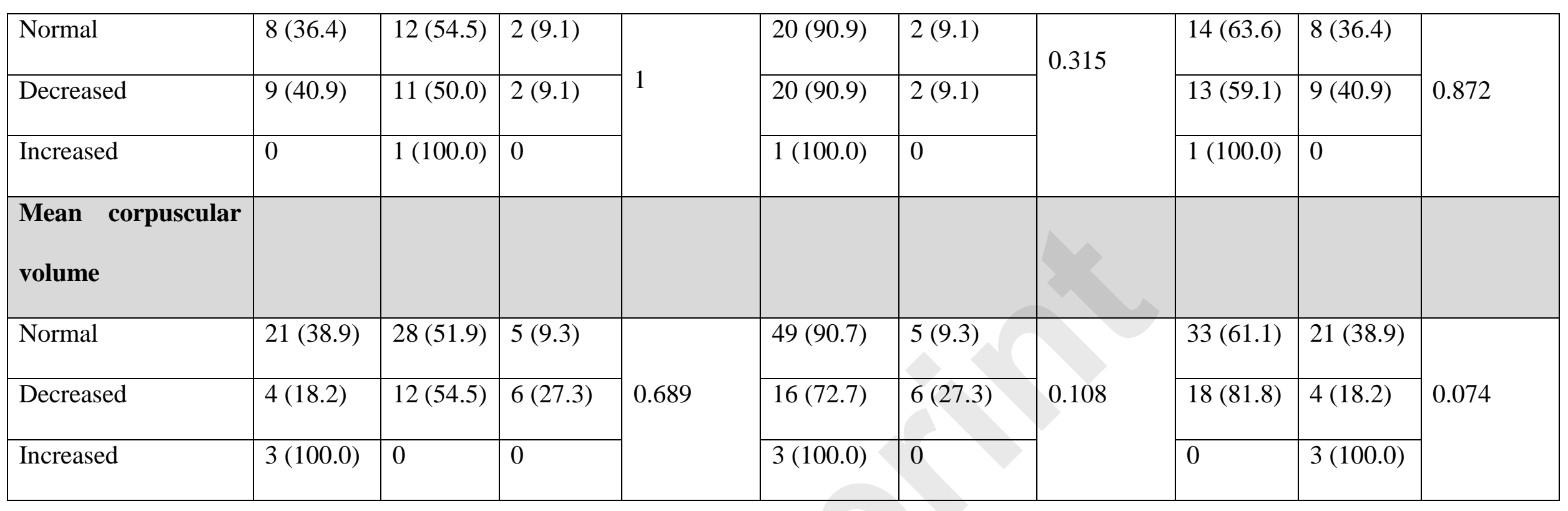


Table VII. EPCR c.6936A>G genotype distribution among clinical characteristics.

\begin{tabular}{|c|c|c|c|c|c|c|c|c|c|c|}
\hline \multirow[t]{2}{*}{ Characteristics } & \multicolumn{3}{|c|}{$E P C R$ c.6936A>G } & \multirow[t]{2}{*}{$p$ value } & \multicolumn{2}{|c|}{ Recessive model } & \multirow[t]{2}{*}{$p$ value } & \multicolumn{2}{|c|}{ Dominant model } & \multirow[t]{3}{*}{$p$ value } \\
\hline & AA & $\mathrm{AG}$ & GG & & $\mathrm{AG}+\mathrm{AA}$ & GG & & $\mathrm{AG}+\mathrm{GG}$ & AA & \\
\hline & $\mathrm{N}(\%)$ & $\mathrm{N}(\%)$ & $\mathrm{N}(\%)$ & & $\mathrm{N}(\%)$ & $\mathrm{N}(\%)$ & & $\mathrm{N}(\%)$ & $\mathrm{N}(\%)$ & \\
\hline \multirow{2}{*}{\multicolumn{11}{|c|}{$\begin{array}{l}\text { Venous } \\
\text { thrombosis }\end{array}$}} \\
\hline & & & & & & & & & & \\
\hline- & $9(14.5)$ & $41(66.1)$ & $12(19.4)$ & \multirow{2}{*}{0.780} & $50(80.6)$ & $12(19.4)$ & \multirow{2}{*}{0.475} & $53(85.5)$ & $9(14.5)$ & \multirow{2}{*}{0.655} \\
\hline+ & $2(20.0)$ & $7(70.0)$ & $1(10.0)$ & & $9(90.0)$ & $1(10.0)$ & & $8(80.0)$ & $2(20.0)$ & \\
\hline \multirow{2}{*}{\multicolumn{11}{|c|}{$\begin{array}{l}\text { Arterial } \\
\text { thrombosis }\end{array}$}} \\
\hline & & & & & & & & & & \\
\hline- & 7 (14.9) & $33(70.2)$ & 7 (14.9) & \multirow{2}{*}{0.604} & $40(85.1)$ & $7(14.9)$ & \multirow{2}{*}{0.515} & $40(85.1)$ & 7 (14.9) & \multirow{2}{*}{0.515} \\
\hline+ & $6(20.7)$ & $17(58.6)$ & $6(20.7)$ & & $23(79.3)$ & $6(20.7)$ & & $23(79.3)$ & $6(20.7)$ & \\
\hline \multirow{2}{*}{\multicolumn{11}{|c|}{$\begin{array}{l}\text { Incidence of } \\
\text { thrombosis }\end{array}$}} \\
\hline & & & & & & & & & & \\
\hline- & $7(13.5)$ & $37(71.2)$ & $8(15.4)$ & \multirow{2}{*}{0.772} & $44(84.6)$ & $8(15.4)$ & \multirow{2}{*}{0.619} & $45(86.5)$ & $7(13.5)$ & \multirow{2}{*}{0.677} \\
\hline+ & $6(16.7)$ & $23(63.9)$ & 7 (19.4) & & $7(19.4)$ & $29(80.6)$ & & $30(83.3)$ & $6(16.7)$ & \\
\hline
\end{tabular}




\begin{tabular}{|c|c|c|c|c|c|c|c|c|c|c|}
\hline $\begin{array}{l}\text { Mean } \\
\text { volume }\end{array}$ & & & & & & & & & & \\
\hline Normal & $3(13.6)$ & $18(81.8)$ & $1(4.5)$ & \multirow{3}{*}{0.529} & $21(95.5)$ & $1(4.5)$ & \multirow{3}{*}{0.299} & $19(86.4)$ & $3(13.6)$ & \multirow{3}{*}{0.934} \\
\hline Decreased & 4 (18.2) & $12(54.5)$ & $6(27.3)$ & & $16(72.7)$ & $6(27.3)$ & & $18(81.8)$ & $4(18.2)$ & \\
\hline Increased & 0 & $1(100.0)$ & 0 & & $1(100.0)$ & 0 & & $1(100.0)$ & 0 & \\
\hline \multirow{2}{*}{\multicolumn{11}{|c|}{$\begin{array}{l}\text { Mean corpuscular } \\
\text { volume }\end{array}$}} \\
\hline & & & & & & & & & & \\
\hline Normal & $5(9.3)$ & $39(72.2)$ & $10(18.5)$ & \multirow{3}{*}{0.127} & $44(81.5)$ & $10(18.5)$ & \multirow{3}{*}{0.301} & $49(90.7)$ & $5(9.3)$ & \multirow{3}{*}{0.096} \\
\hline Decreased & $7(31.8)$ & $13(59.1)$ & $2(9.1)$ & & $20(90.9)$ & $2(9.1)$ & & $15(68.2)$ & $7(31.8)$ & \\
\hline Increased & 0 & $3(100.0)$ & 0 & & $3(100.0)$ & 0 & & $3(100.0)$ & 0 & \\
\hline
\end{tabular}


Table VIII. PROC c.565C >T genotype distribution among clinical characteristics.

\begin{tabular}{|c|c|c|c|c|c|c|c|c|c|c|}
\hline \multirow[t]{3}{*}{ Characteristics } & \multicolumn{3}{|c|}{$P R O C$ c.565C $>\mathrm{T}$} & \multirow[t]{3}{*}{$p$ value } & \multicolumn{2}{|c|}{ Recessive model } & \multirow[t]{3}{*}{$p$ value } & \multicolumn{2}{|c|}{ Dominant model } & \multirow[t]{3}{*}{$p$ value } \\
\hline & $\mathrm{CC}$ & CT & TT & & $\mathrm{CT}+\mathrm{CC}$ & TT & & $\mathrm{CT}+\mathrm{TT}$ & $\mathrm{CC}$ & \\
\hline & $\mathrm{N}(\%)$ & $\mathrm{N}(\%)$ & $\mathrm{N}(\%)$ & & $\mathrm{N}(\%)$ & $\mathrm{N}(\%)$ & & $\mathrm{N}(\%)$ & $\mathrm{N}(\%)$ & \\
\hline \multicolumn{11}{|l|}{$\begin{array}{l}\text { Venous } \\
\text { thrombosis }\end{array}$} \\
\hline- & $28(45.2)$ & $19(30.6)$ & $15(24.2)$ & \multirow{2}{*}{0.555} & $47(75.8)$ & $15(24.2)$ & \multirow{2}{*}{0.316} & $34(54.8)$ & $28(45.2)$ & \multirow{2}{*}{0.383} \\
\hline+ & $6(60.0)$ & $3(30.0)$ & $1(10.0)$ & & $9(90.0)$ & $1(10.0)$ & & $4(40.0)$ & $6(60.0)$ & \\
\hline \multicolumn{11}{|l|}{$\begin{array}{l}\text { Arterial } \\
\text { thrombosis }\end{array}$} \\
\hline- & $21(44.7)$ & $14(29.8)$ & $12(25.5)$ & \multirow{2}{*}{0.387} & 35 (74.5) & $12(25.5)$ & \multirow{2}{*}{0.223} & $26(55.3)$ & $21(44.7)$ & \multirow{2}{*}{0.238} \\
\hline+ & $17(58.6)$ & $8(27.6)$ & $4(13.8)$ & & $25(86.2)$ & $4(13.8)$ & & $12(41.4)$ & $17(58.6)$ & \\
\hline \multicolumn{11}{|l|}{$\begin{array}{l}\text { Incidence of } \\
\text { thrombosis }\end{array}$} \\
\hline- & $23(44.2)$ & $15(28.8)$ & $14(26.9)$ & \multirow[t]{2}{*}{0.282} & $38(73.1)$ & $14(26.9)$ & \multirow{2}{*}{0.144} & $29(55.8)$ & $23(44.2)$ & \multirow{2}{*}{0.193} \\
\hline+ & $21(58.3)$ & $10(27.8)$ & $5(13.9)$ & & $31(86.1)$ & $5(13.9)$ & & $15(41.7)$ & $21(58.3)$ & \\
\hline
\end{tabular}




\begin{tabular}{|c|c|c|c|c|c|c|c|c|c|c|}
\hline $\begin{array}{l}\text { Mean pla } \\
\text { volume }\end{array}$ & & & & & & & & & & \\
\hline Normal & $13(59.1)$ & $6(27.3)$ & $3(13.6)$ & \multirow{3}{*}{0.834} & $19(86.4)$ & $3(13.6)$ & \multirow{3}{*}{0.552} & $9(40.9)$ & $13(59.1)$ & \multirow{3}{*}{0.555} \\
\hline Decreased & $11(50.0)$ & $7(31.8)$ & 4 (18.2) & & $18(81.8)$ & $4(18.2)$ & & $11(50.0)$ & $11(50.0)$ & \\
\hline Increased & $1(100.0)$ & 0 & 0 & & $1(100.0)$ & 0 & & 0 & $1(100.0)$ & \\
\hline \multicolumn{11}{|c|}{$\begin{array}{l}\text { Mean } \\
\text { corpuscular } \\
\text { volume }\end{array}$} \\
\hline Normal & $26(48.1)$ & $16(29.6)$ & $12(22.2)$ & \multirow{3}{*}{0.380} & $42(77.8)$ & $12(22.2)$ & \multirow{3}{*}{0.223} & $28(51.9)$ & $26(48.1)$ & \multirow{3}{*}{0.756} \\
\hline Decreased & $11(50.0)$ & $8(36.4)$ & $3(13.6)$ & & $19(86.4)$ & $3(13.6)$ & & $11(50.0)$ & $11(50.0)$ & \\
\hline Increased & $1(33.3)$ & 0 & $2(66.7)$ & & $1(33.3)$ & $2(66.7)$ & & $2(66.7)$ & $1(33.3)$ & \\
\hline
\end{tabular}


Table IX. MTHFR c.677C >T genotype distribution among clinical characteristics.

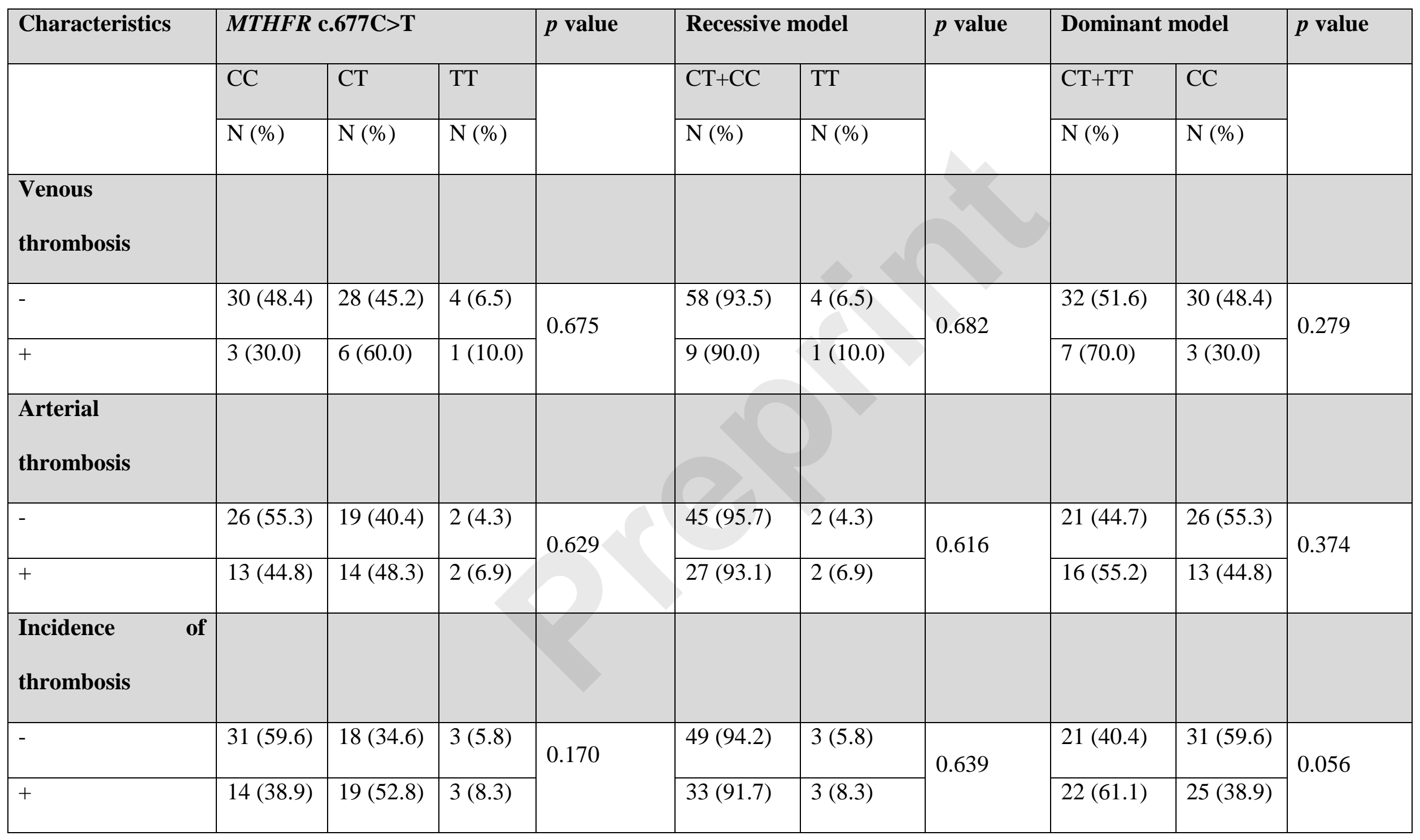




\begin{tabular}{|c|c|c|c|c|c|c|c|c|c|c|}
\hline $\begin{array}{l}\text { Mean } \\
\text { volume }\end{array}$ & & & & & & & & & & \\
\hline Normal & $8(36.4)$ & $13(59.1)$ & $1(4.5)$ & \multirow{3}{*}{0.427} & $21(95.5)$ & $1(4.5)$ & \multirow{3}{*}{1} & $14(63.6)$ & $8(36.4)$ & \multirow{3}{*}{0.272} \\
\hline Decreased & $13(59.1)$ & $7(31.8)$ & $2(9.1)$ & & $20(90.9)$ & $2(9.1)$ & & $9(40.9)$ & $13(59.1)$ & \\
\hline Increased & 0 & $1(100.0)$ & 0 & & $1(100.0)$ & 0 & & $1(100.0)$ & 0 & \\
\hline \multicolumn{11}{|c|}{$\begin{array}{l}\text { Mean corpuscular } \\
\text { volume }\end{array}$} \\
\hline Normal & $26(48.1)$ & $23(42.6)$ & $5(9.3)$ & \multirow{3}{*}{0.872} & $49(90.7)$ & $5(9.3)$ & \multirow{3}{*}{0.656} & $28(51.9)$ & $26(48.1)$ & \multirow{3}{*}{0.714} \\
\hline Decreased & $11(50.0)$ & $10(45.5)$ & $1(4.5)$ & & $21(95.5)$ & $1(4.5)$ & & $11(50.0)$ & $11(50.0)$ & \\
\hline Increased & $2(66.7)$ & $1(33.3)$ & 0 & & $3(100.0)$ & 0 & & $1(33.3)$ & $2(66.7)$ & \\
\hline
\end{tabular}


Table X. MTHFR c.1298A>C genotype distribution among clinical characteristics.

\begin{tabular}{|c|c|c|c|c|c|c|c|c|c|c|}
\hline \multirow[t]{3}{*}{ Characteristics } & \multicolumn{3}{|c|}{ MTHFR c.1298A >C } & \multirow[t]{3}{*}{$p$ value } & \multicolumn{2}{|c|}{ Recessive model } & \multirow[t]{3}{*}{$p$ value } & \multicolumn{2}{|c|}{ Dominant model } & \multirow[t]{3}{*}{$p$ value } \\
\hline & AA & $\mathrm{AC}$ & $\mathrm{CC}$ & & $\mathrm{AC}+\mathrm{AA}$ & $\mathrm{CC}$ & & $\mathrm{AC}+\mathrm{CC}$ & AA & \\
\hline & $\mathrm{N}(\%)$ & $\mathrm{N}(\%)$ & $\mathrm{N}(\%)$ & & $\mathrm{N}(\%)$ & $\mathrm{N}(\%)$ & & $\mathrm{N}(\%)$ & $\mathrm{N}(\%)$ & \\
\hline \multirow{2}{*}{\multicolumn{11}{|c|}{$\begin{array}{l}\text { Venous } \\
\text { thrombosis }\end{array}$}} \\
\hline & & & & & & & & & & \\
\hline- & $27(43.5)$ & $27(43.5)$ & $8(12.9)$ & \multirow{2}{*}{0.019} & $54(87.1)$ & $8(12.9)$ & \multirow{2}{*}{0.163} & $35(56.5)$ & $27(43.5)$ & \multirow{2}{*}{0.120} \\
\hline+ & $7(70.0)$ & 0 & $3(30.0)$ & & $7(70.0)$ & $3(30.0)$ & & $3(30.0)$ & $7(70.0)$ & \\
\hline \multirow{2}{*}{\multicolumn{11}{|c|}{$\begin{array}{l}\text { Arterial } \\
\text { thrombosis }\end{array}$}} \\
\hline & & & & & & & & & & \\
\hline- & $20(42.6)$ & $19(40.4)$ & $8(17.0)$ & \multirow{2}{*}{0.995} & $39(83.0)$ & $8(17.0)$ & \multirow{2}{*}{0.980} & $27(57.4)$ & $20(42.6)$ & \multirow{2}{*}{0.920} \\
\hline+ & $12(41.4)$ & $12(41.4)$ & $5(17.2)$ & & $24(82.8)$ & $5(17.2)$ & & $17(58.6)$ & $12(41.4)$ & \\
\hline \multirow{2}{*}{\multicolumn{11}{|c|}{$\begin{array}{l}\text { Incidence of } \\
\text { thrombosis }\end{array}$}} \\
\hline & & & & & & & & & & \\
\hline- & $19(36.5)$ & $22(42.3)$ & $11(21.2)$ & \multirow{2}{*}{0.453} & $41(78.8)$ & $11(21.2)$ & \multirow{2}{*}{0.600} & $33(63.5)$ & $19(36.5)$ & \multirow{2}{*}{0.208} \\
\hline+ & $18(50.0)$ & $12(33.3)$ & $6(16.7)$ & & $30(83.3)$ & $6(16.7)$ & & $18(50.0)$ & $18(50.0)$ & \\
\hline
\end{tabular}




\begin{tabular}{|l|l|l|l|l|l|l|l|l|l|}
\hline Mean platelet & & & & & & \\
volume & & & & & & & \\
\end{tabular}


Table XI. $M S$ c. $2756 \mathrm{~A}>\mathrm{G}$ genotype distribution among clinical characteristics.

\begin{tabular}{|c|c|c|c|c|c|c|c|c|c|c|}
\hline \multirow[t]{2}{*}{ Characteristics } & \multicolumn{3}{|c|}{$M S$ c.2756A>G } & \multirow[t]{2}{*}{$p$ value } & \multicolumn{2}{|c|}{ Recessive model } & \multirow[t]{2}{*}{$p$ value } & \multicolumn{2}{|c|}{ Dominant model } & \multirow[t]{3}{*}{$p$ value } \\
\hline & AA & $\mathrm{AG}$ & GG & & $\mathrm{AG}+\mathrm{AA}$ & GG & & $\mathrm{AG}+\mathrm{CC}$ & GG & \\
\hline & $\mathrm{N}(\%)$ & $\mathrm{N}(\%)$ & $\mathrm{N}(\%)$ & & $\mathrm{N}(\%)$ & $\mathrm{N}(\%)$ & & $\mathrm{N}(\%)$ & $\mathrm{N}(\%)$ & \\
\hline \multirow{2}{*}{\multicolumn{11}{|c|}{$\begin{array}{l}\text { Venous } \\
\text { thrombosis }\end{array}$}} \\
\hline & & & & & & & & & & \\
\hline- & $37(59.7)$ & $22(35.5)$ & $3(4.8)$ & \multirow{2}{*}{0.505} & $59(95.2)$ & $3(4.8)$ & \multirow{2}{*}{0.477} & $25(40.3)$ & $37(59.7)$ & \multirow{2}{*}{0.218} \\
\hline+ & $8(80.0)$ & $2(20.0)$ & 0 & & $10(100.0)$ & Y & & $2(20.0)$ & $8(80.0)$ & \\
\hline \multirow{2}{*}{\multicolumn{11}{|c|}{$\begin{array}{l}\text { Arterial } \\
\text { thrombosis }\end{array}$}} \\
\hline & & & & & & & & & & \\
\hline- & $27(57.4)$ & $18(38.3)$ & $2(4.3)$ & \multirow{2}{*}{0.833} & $45(95.7)$ & $2(4.3)$ & \multirow{2}{*}{0.861} & $20(42.6)$ & $27(57.4)$ & \multirow{2}{*}{0.484} \\
\hline+ & $19(65.5)$ & $9(31.0)$ & $1(3.4)$ & & $28(96.6)$ & $1(3.4)$ & & $10(34.5)$ & $19(65.5)$ & \\
\hline \multirow{2}{*}{\multicolumn{11}{|c|}{$\begin{array}{l}\text { Incidence of } \\
\text { thrombosis }\end{array}$}} \\
\hline & & & & & & & & & & \\
\hline- & $30(57.7)$ & $19(36.5)$ & $2(5.8)$ & \multirow{2}{*}{0.651} & $49(94.2)$ & $3(5.8)$ & \multirow{2}{*}{0.508} & $22(42.3)$ & $30(57.7)$ & \multirow{2}{*}{0.395} \\
\hline+ & $24(66.7)$ & $11(30.6)$ & $1(2.8)$ & & 35 (97.2) & $1(2.8)$ & & $12(33.3)$ & $24(66.7)$ & \\
\hline
\end{tabular}




\begin{tabular}{|c|c|c|c|c|c|c|c|c|c|c|}
\hline $\begin{array}{l}\text { Mean p } \\
\text { volume }\end{array}$ & & & & & & & & & & \\
\hline Normal & $14(63.6)$ & $8(36.4)$ & 0 & \multirow{3}{*}{0.707} & $22(100.0)$ & 0 & \multirow{3}{*}{0.622} & $8(36.4)$ & $14(63.6)$ & \multirow{3}{*}{0.728} \\
\hline Decreased & $14(63.6)$ & $7(31.8)$ & $1(4.5)$ & & $21(95.5)$ & $1(4.5)$ & & $8(36.4)$ & $14(63.6)$ & \\
\hline Increased & 0 & $1(100.0)$ & 0 & & $1(100.0)$ & 0 & & $1(100.0)$ & 0 & \\
\hline \multirow{2}{*}{\multicolumn{11}{|c|}{$\begin{array}{l}\text { Mean } \\
\text { corpuscular } \\
\text { volume }\end{array}$}} \\
\hline & & & & & & & & & & \\
\hline Normal & $34(63.0)$ & $18(33.3)$ & $3(3.7)$ & \multirow{3}{*}{0.301} & $52(96.3)$ & $2(3.7)$ & \multirow{3}{*}{0.187} & $20(37.0)$ & $34(63.0)$ & \multirow{3}{*}{0.910} \\
\hline Decreased & $12(54.5)$ & 9 (40.9) & $1(4.5)$ & & $21(95.5)$ & $1(4.5)$ & & $10(45.5)$ & $12(54.5)$ & \\
\hline Increased & $2(66.7)$ & 0 & $1(33.3)$ & & $2(66.7)$ & $1(33.3)$ & & $1(33.3)$ & $2(66.7)$ & \\
\hline
\end{tabular}




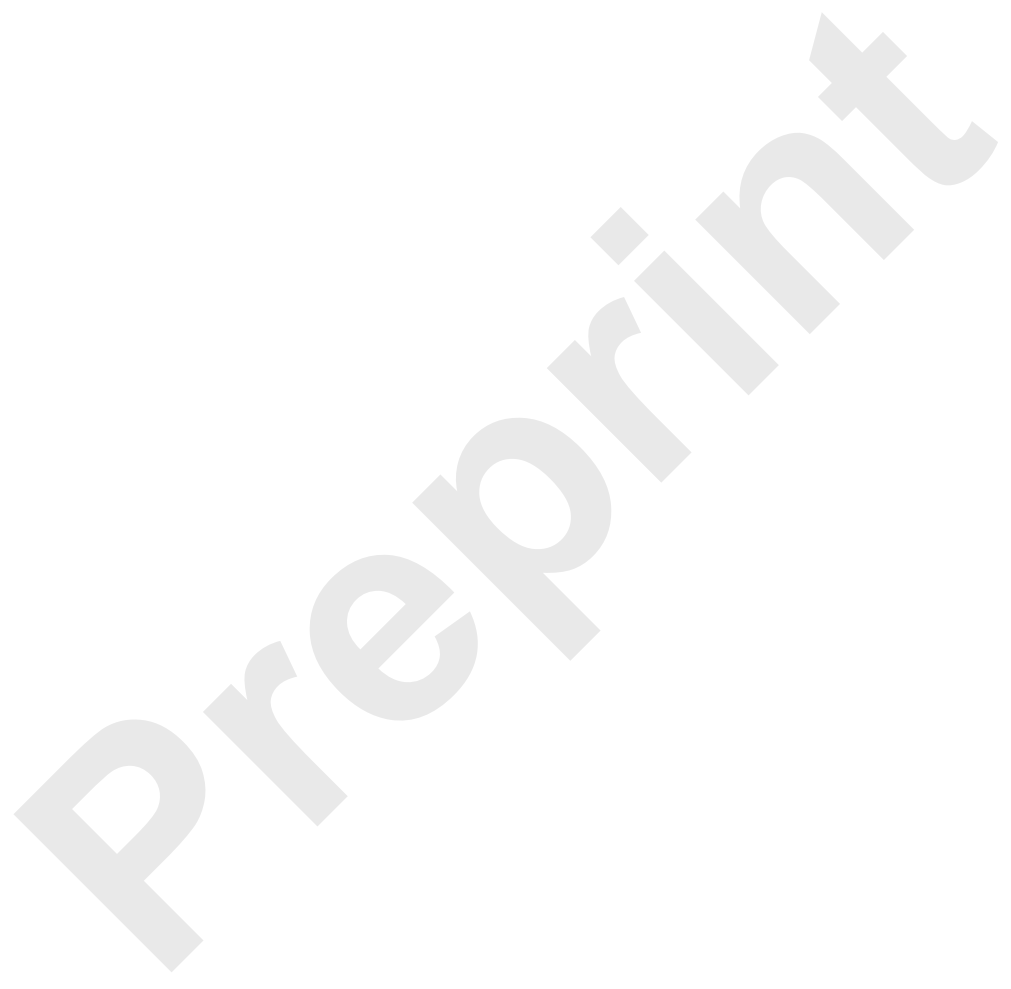

